\title{
Effects of Population Growth on Urban Extent and Supply of Water and Sanitation: Case of Nakuru Municipality, Kenya
}

\author{
Elizabeth W. Muoria (corresponding Author) \\ Department of Environmental Science Egerton University \\ P.O. Box 536 Egerton Njoro, Kenya \\ Tel: 254-721-282-232Ｅ-mail: muorializ07@gmail.com
}

\author{
Prof. Wilkister N. Moturi \\ Department of Environmental Science \\ P.O. Box 536, Egerton Njoro, Kenya \\ Tel: 254-721-566-802Ｅ-mail: moturi33@yahoo.com \\ Dr. George W. Eshiamwata \\ Natural Sciences, Kenya National Commission for UNESCO \\ P.O. Box 72017-00200, Nairobi, Kenya \\ Tel: 254-723-812-990Ｅ-mail: gweshiamwata@gmail.com
}

Received: December 4, 2018 Accepted: December 20, 2018 Published: January 8, 2018

doi:10.5296/emsd.v8i1.14193ＵRL: https://doi.org/10.5296/emsd.v8i1.14193

\begin{abstract}
Urbanization causes changes in social and environmental conditions with most of these changes impacting on the efficient provision of essential services such as water and sanitation. Nakuru Municipality was observed to be the fastest growing urban area in East and Central Africa. Research on patterns and trends of urban and population increase and their implication on water service provision and sanitation in urban Nakuru is very scanty. This paper presents findings from an assessment of the effects of population growth between 1999 and 2017 on urban extent and supply of water and sewage reticulation in Nakuru municipality
\end{abstract}


and surrounding peri-urban areas. Data was collected through remote sensing and administration of questionnaires to urban Nakuru residents and key informants from NAWASSCO respectively to elicit information on the water supply network and sewerage reticulation in Nakuru municipality for the period 1989-2014. Geographic Information System (GIS) was used to analyze the data on time series. The results indicate that the population of Nakuru municipality and surrounding peri-urban areas has increased by $56.8 \%$ whereas that of built-up area has increased by $182.5 \%$ in the same period through densification of the urban core and expansion to the peri-urban areas characterized by urban sprawl. The water supply network and sewerage reticulation increased by $236 \mathrm{~km}$ and $89 \mathrm{~km}$ respectively within Nakuru municipality. The analysis of the maps shows that water supply network and sewerage reticulation are concentrated in the area around the urban core with very little spread. This means that the residents on the outskirts of Nakuru Municipality are not well served by the water supply network and sewerage reticulation. The study recommends involvement of all stakeholders in urban planning and in the water sector in order to increase water supply network and sewerage reticulation coverage both in the urban and peri-urban areas.

Keywords: Urban growth, Sprawl, Water supply, Reticulation, Remote sensing, Geographic Information System (GIS)

\section{Introduction}

Urbanization has been identified as one of the most important components of global transformations (Garza, 2004). Recent studies have shown that more than half of the global population is found in urban areas and this proportion is expected to continue increasing in years to come. The global proportion of urban population rose dramatically from $13 \%$ (220 million) in 1900 , to $29 \%$ ( 732 million) in 1950 , to $49 \%$ (3.2 billion) in 2005 , to $57.7 \%$ (4.1 billion) 2017 and it is predicted that by $205060 \%$ and $85.9 \%$ of the developing and developed world respectively will be urbanized (UN, 2017).

According to UN (2010), African society will become predominantly urban by 2025 . Africa's urban population is projected to more than double, from 295 million in 2000 to 748 million by 2030 so that within 25 years, Africa's urban population will be larger than that in North America, Europe, or Latin America. In the sub-Saharan Africa for instance, urban population grew from $15 \%$ in 1950 to $32 \%$ in 1990 to $40.2 \%$ in 2017 , a further $54-60 \%$ growth is expected by 2030 (UN, 2017). African urbanization has not been accompanied by economic development as compared to Asia and Latin America (NRC-USA, 2003). African cities and towns have shown noticeable increase in urban growth and this has been linked to environmental degradation in these cities and towns (Freudenberg et al., 2005). The changes brought about by increased urban growth and their impacts require careful consideration so as to effectively balance the positive aspects of development and its negative impacts in order to conserve environmental resources and increase socio-economic welfare. In particular access to safe drinking water, sanitation, drainage, and garbage collection are crucial elements of urban growth that should be addressed to ensure human and environmental health.

Kenya's population living in urban areas has been increasing and it is predicted that by 2050 


\section{Macrothink}

there will be 42.1 million urban dwellers (UN, 2015) thus showing significant structural transformations demographically, socio-economically and spatially. This growth will be distributed in urban centres of different sizes, mainly in the small and medium-sized ones within counties outside Nairobi region (UN-HABITAT, 2014). The major urban areas that will constitute half of the urban population include Nairobi, Mombasa, Kisumu, Nakuru, Eldoret, Kikuyu, Ruiru, Kangundo-Tala, Naivasha, Thika and Machakos (NCPD, 2013). Consequently, the demand for housing, water and sanitation services, education, and health services has increased and the urban environment has worsened due to congestion and unplanned developments.

Rapid urbanization in Kenya has also not been accompanied by commensurate growth of infrastructure for water supply and sanitation services. Inadequate supply of housing for a majority of the urban dwellers that are mainly urban low-income groups live in substandard housing in unplanned peri-urban settlements without adequate water supply and sanitation services. According to UN-HABITAT (2008), only 30\% of urban towns are planned. Majority of medium sized and small towns are faced with significant peri-urbanization, to the extent that several of them have a peri-urban population double that of the reported urban core population (KNBS, 2010). It is estimated that about 50 percent of Kenya's urban population live in unplanned settlements lacking in basic infrastructure provision and services (NCPD), 2013).

Nakuru town has experienced unprecedented growth. During the past 40 years, the population of Nakuru town increased with a factor of six from 47,151 people in 1969 to 309424 in 2009 making her the fourth largest town in Kenya (after Nairobi, Mombasa and Kisumu) (KNBS, 2010). Due to this tremendous increase in its population, Nakuru town is experiencing urban sprawl which has seen people move to the peri-urban areas without requisite amenities in place. As noted by Mwangi et al. (2010), the future population is such that $60 \%$ of the local population of urban Nakuru area will be located within the present municipal boundary and the other $40 \%$ in the peri-urban zones with a tendency for these areas to accommodate more and more people.

\section{Study Area}

The study was conducted in Nakuru Municipality and the surrounding peri-urban area. It lies within the Great Rift Valley and covers an area of $1169 \mathrm{Sq} \mathrm{Km}$. It is located between longitudes $35^{\circ} 0^{\prime}$ East and $37^{\circ} 0^{\prime}$ East and latitudes $0^{\circ} 0^{\prime}$ South and $1^{\circ} 0^{\prime}(\mathrm{GoK}, 2008)$. Figure 1 shows the location of the study site. The study area has a bimodal rainfall pattern with three climatic zones II, III, IV. The area has an annual rainfall of between $500 \mathrm{~mm}$ to $1800 \mathrm{~mm}$. The economic activities in the study area are mostly associated with the agricultural production. There are many industries that mostly depend on the agricultural products. 


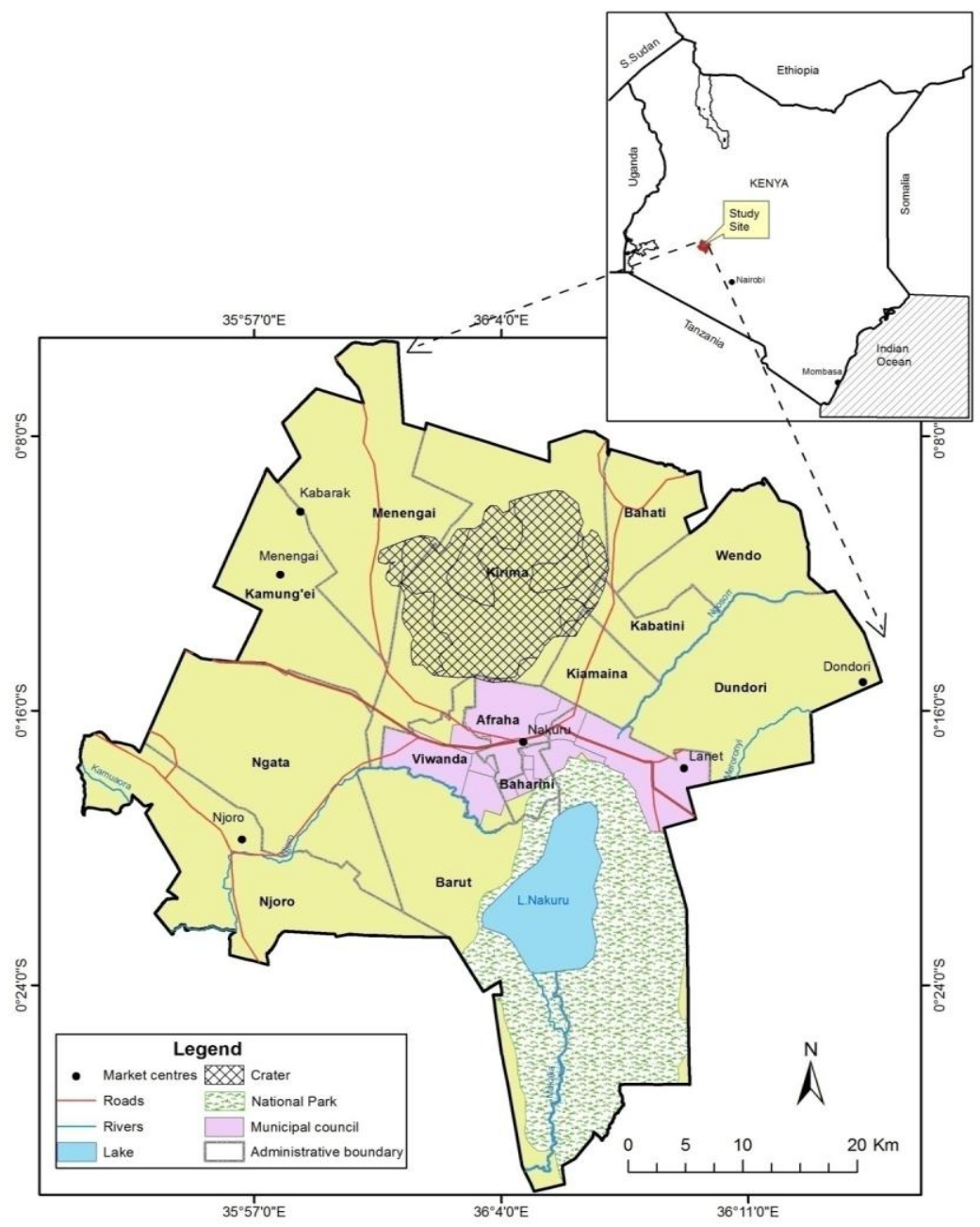

Figure 1. Location of the study area

Source: Map digitized from Survey of Kenya Topomaps

\section{Methods}

A Cross-sectional survey design was used and purposive sampling was done to select key informants taken from Nakuru Water and Sanitation Services Company (NAWASSCO). Primary data was obtained from ten (10) key informants through personal interviews on a face-to-face basis by use of a semi-structured questionnaire. The primary source of the remotely sensed data was Google earth imageries for specific time periods. Vector datasets were obtained from Survey of Kenya and ILRI open source. These were digitized to show administrative boundaries for the study area. Data sets from Survey of Kenya were prepared from topographic map of scale 1:25000. The coordinates in the vector dataset were based on the modified UTM projection. Unit of measure was Km. Statistical Data consisted of population census data for the years under study (1999, 2009 and 2017) obtained from Kenya National Bureau of Statistics (KNBS).

Geographic Information System (GIS) technique was used to analyze both qualitative and quantitative aspects on time series. The analyzed data was displayed using maps and graphs. 


\section{Macrothink

\section{Results}

\subsection{Extent of Urban Growth from 1999-2017}

In order to assess the trend in water supply network and sewerage reticulation, it was important to first examine the extent of urban growth over time with population and in what direction this was taking place. Figure 2 to Figure 4 show the maps of built-up area for the years 1999, 2009 and 2017. The results indicate that in general the population of urban Nakuru has increased by $56.8 \%$ whereas that of built-up area has increased by $182.5 \%$ between 1999 and 2017 through densification of the urban core and expansion to the peri-urban area.

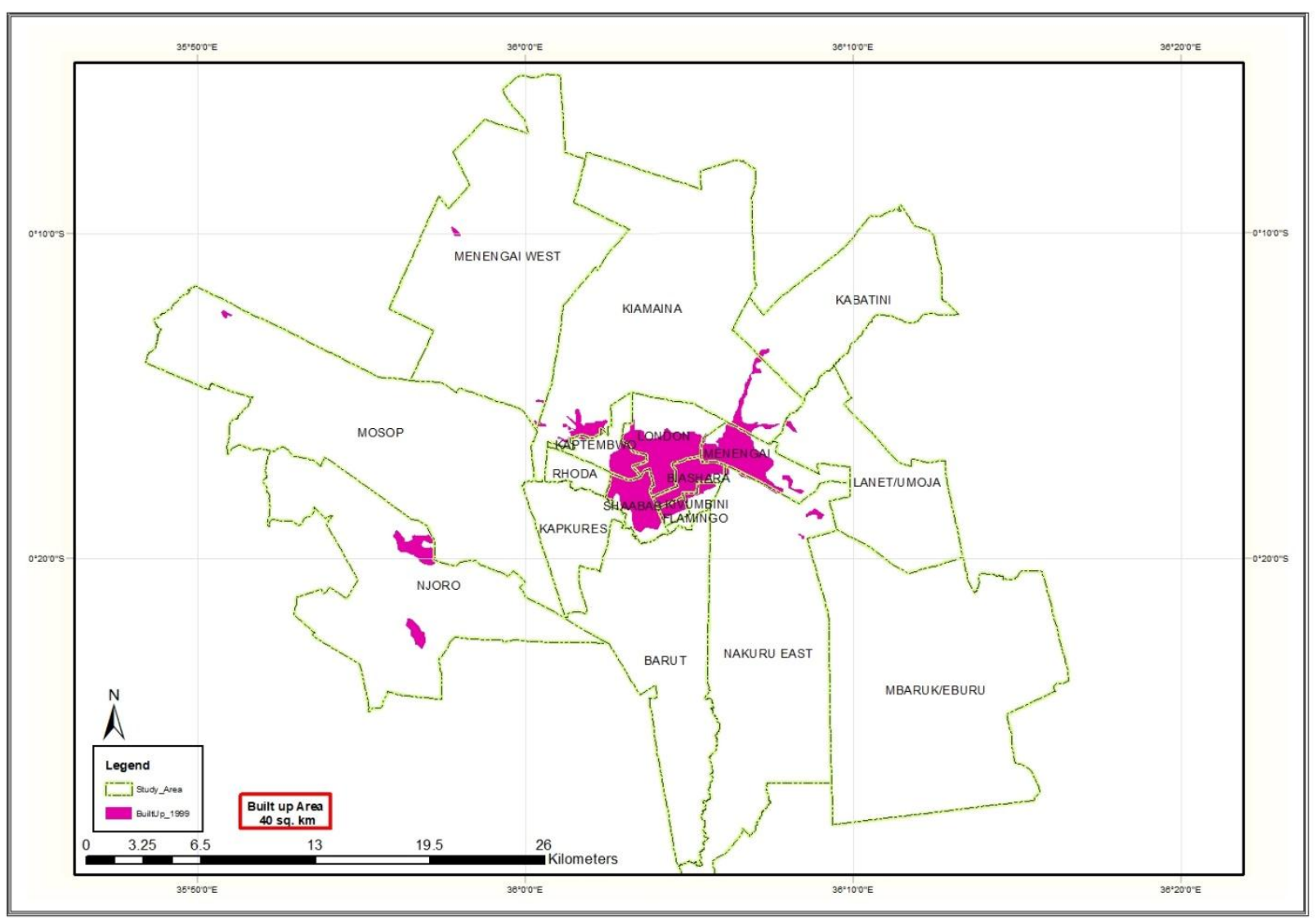

Figure 2. Map of Built-up area 1999 


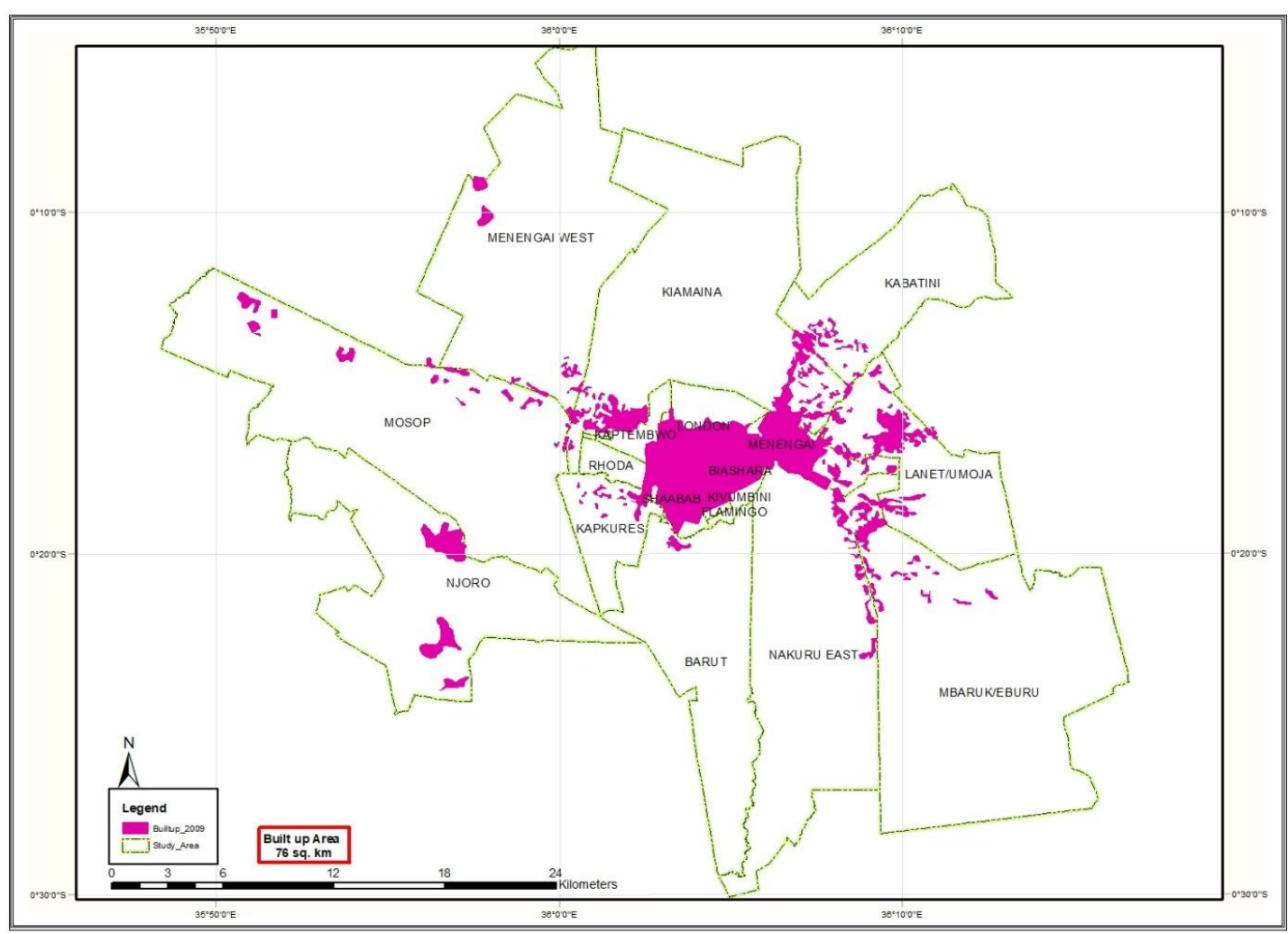

Figure 3. Map of Built-up area 2009

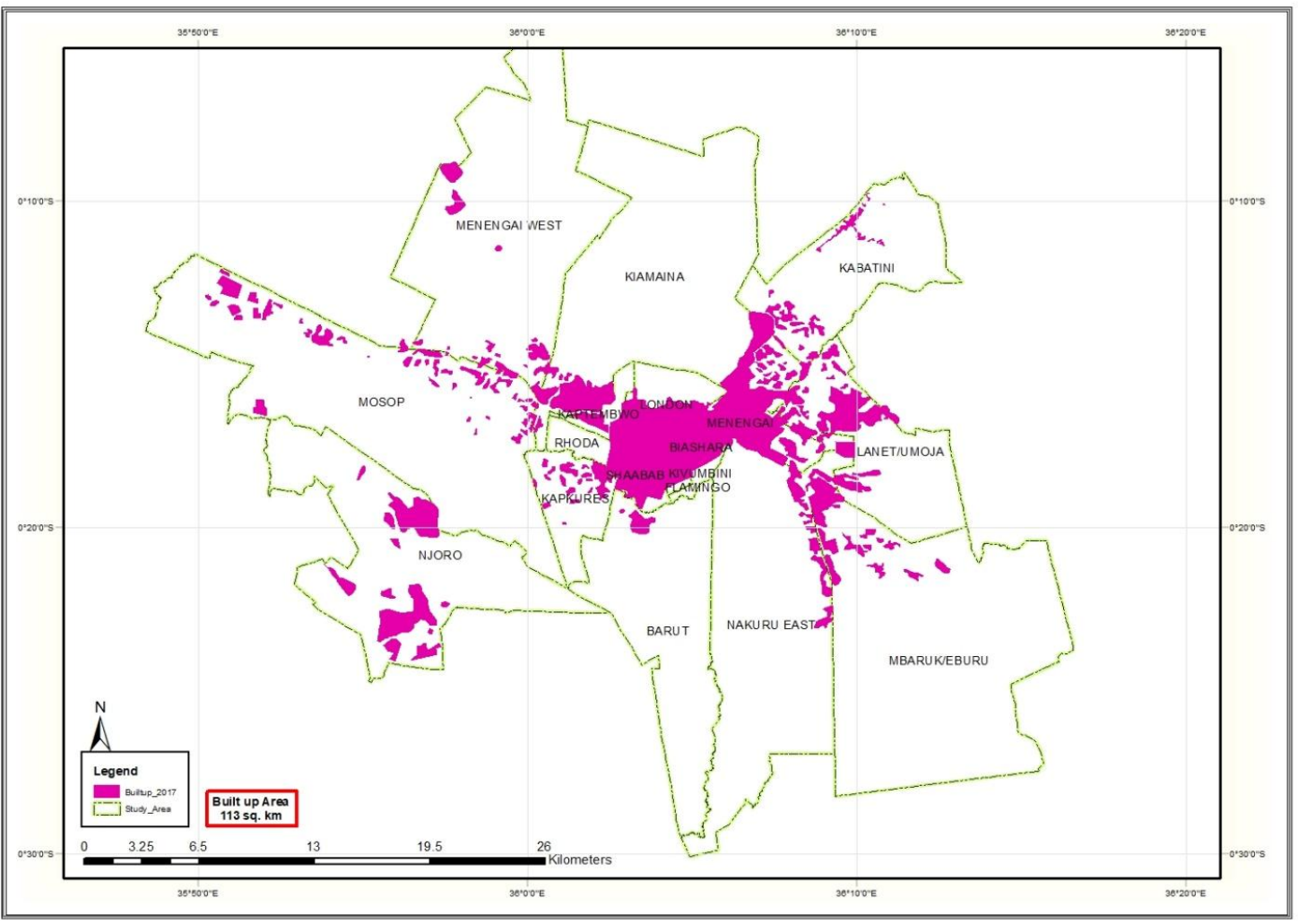

Figure 4. Map of Built-up area 2017 


\section{Ml Macrothink}

The comparison of built-up area and the non-built-up area results in Figure 2 to Figure 4 show that the rate of encroachment of urban land on other land uses has been rapid, with discontinuous patches of urban development characterizing the urban sprawl. Viewed as a time series, built-up area changes have varied substantially over the study period.

By linking population and built -up area data, it was possible to identify that an increase in the population of the study year resulted to an increase in the built-up area. For instance the rate of growth of built area has been taking placing exponentially from 1999 and it is still showing an increasing trend implying a high rate of increase over the years. However population growth shows a slight decline from 2009 as depicted in Figure 5

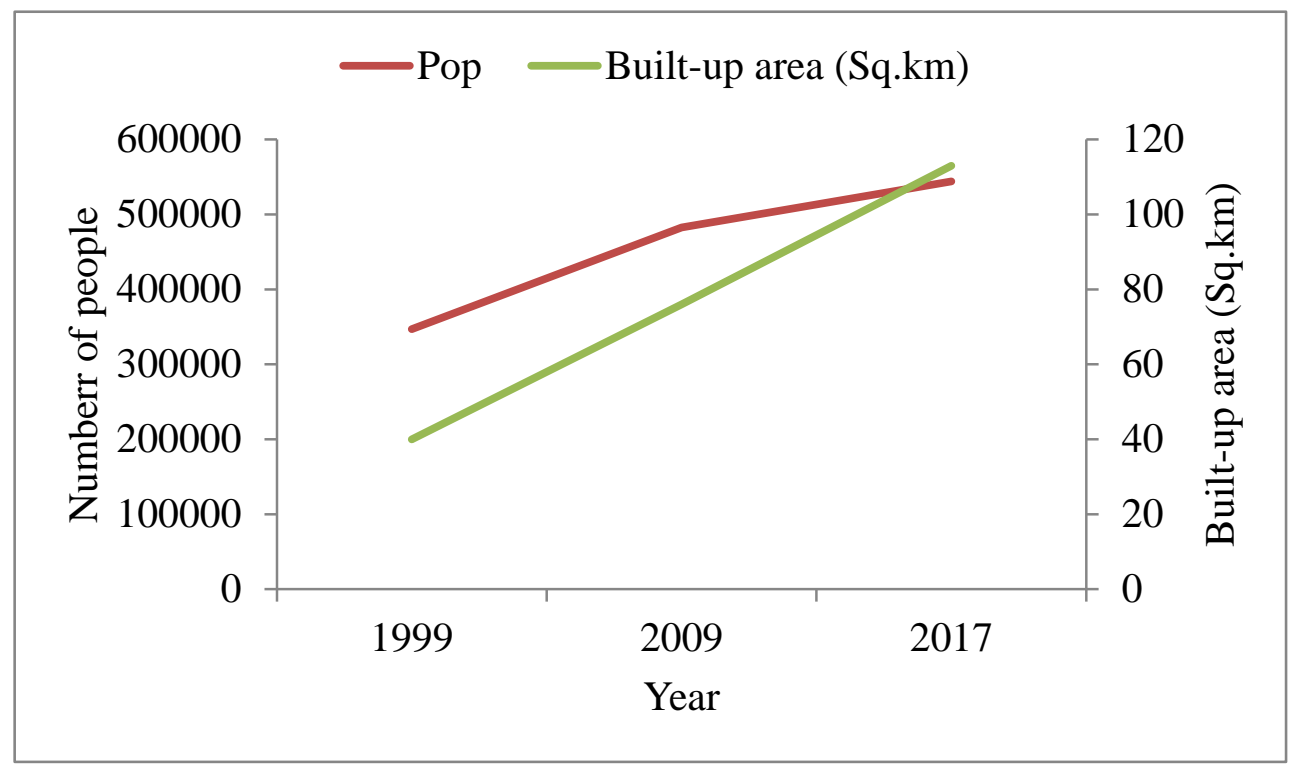

Figure 5. Population size and built-up area from 1999-2017

\subsection{Trends in Water Supply and Sewerage Reticulation 1989-2014}

The trend of water supply network and sewerage reticulation increase was also analyzed for urban area that is served by Nakuru Water and Sanitation Services Company (NAWASSCO). The water supply network and sewerage reticulation depicted in Figure 6 and 7 does not only serve the domestic sector but all other sectors including institutions, commercial and industrial sectors. The findings reveal that from 1989-1999 water supply networks was more concentrated in the area surrounding the CBD. Hence vast areas to the far side of East and West of the CBD were not served by the distribution network thereby affecting water accessibility in these areas. In the period 1999-2014 there has been some effort in extending the water supply network to these areas but it can also be observed that there is still a vast area that remains unsupplied (Figure 7). The results also indicate that overall the water supply network grew by approximately $236 \mathrm{~km}$ in the period1989-2014. The sewerage reticulation increased by about $89 \mathrm{~km}$ for the period 1989-2014. It is observed that over the period under study the sewerage reticulation has remained low and it is confined to the residential areas around the Central Business District (CBD) with very little spread observed in the period 1999-2014. 


\section{I Macrothink}

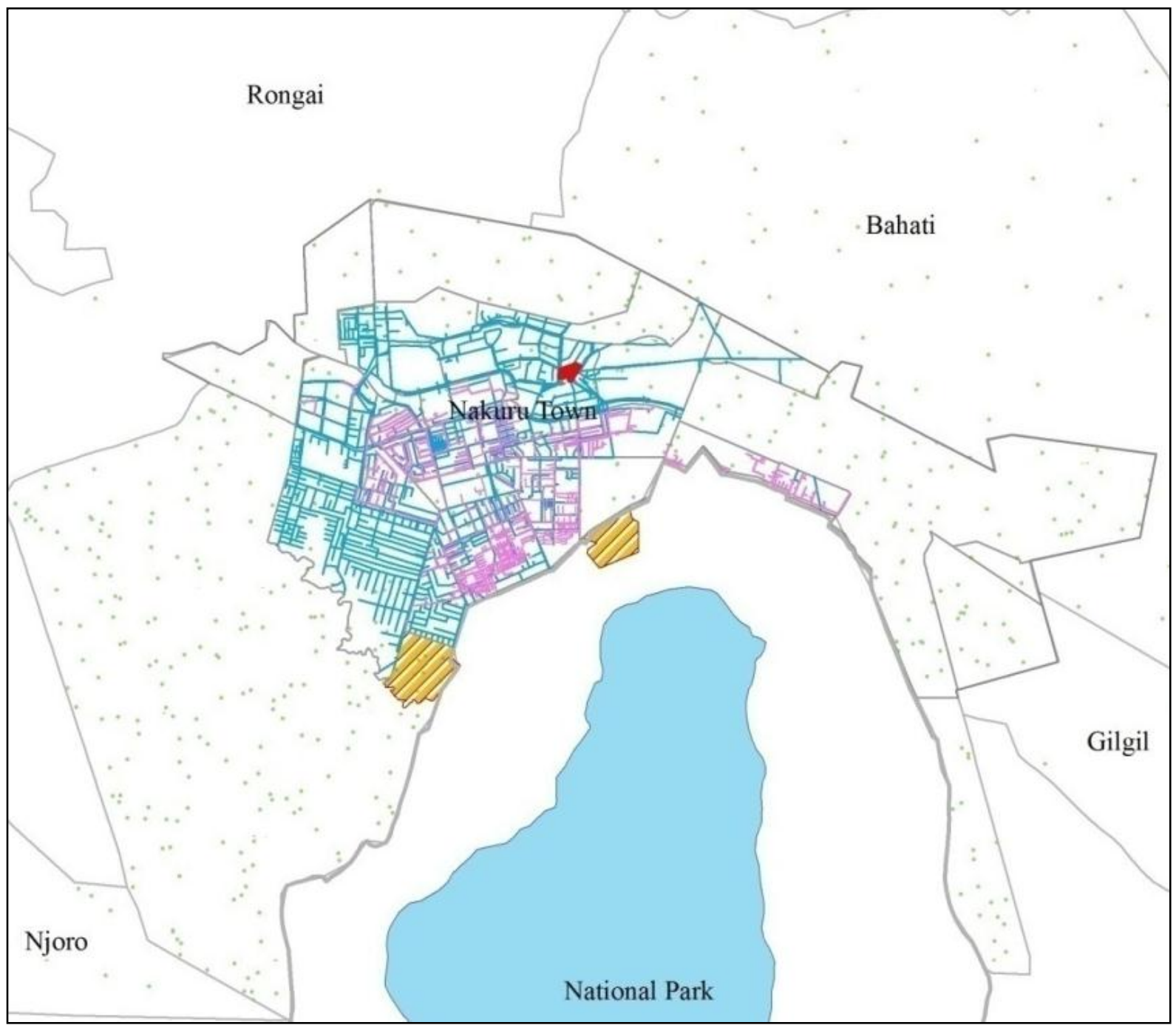

Key
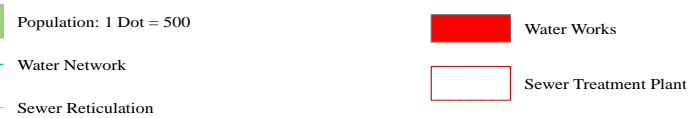

Figure 6. Water supply network and sewerage reticulation for period 1989-1999 


\section{Macrothink}

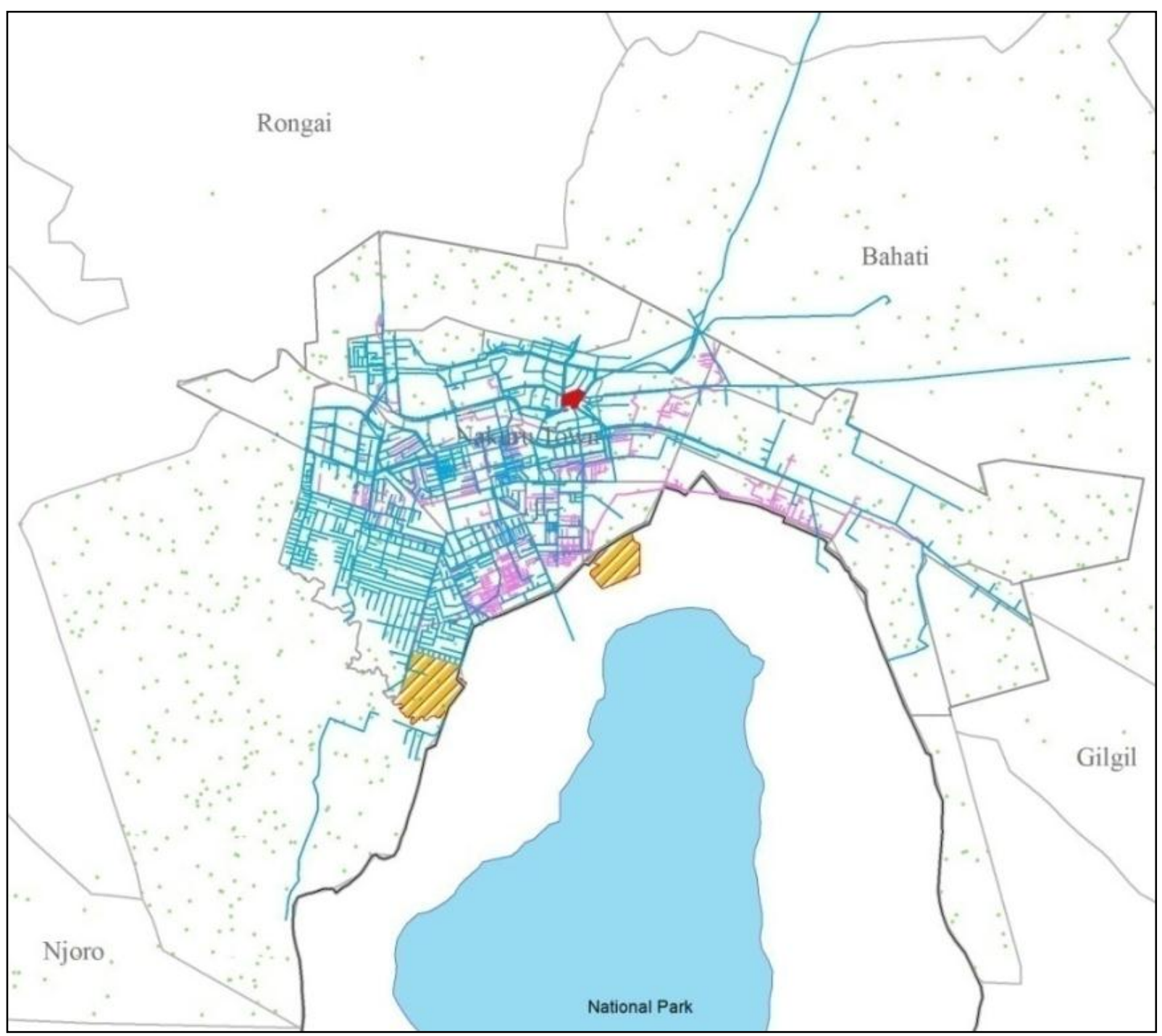

Key
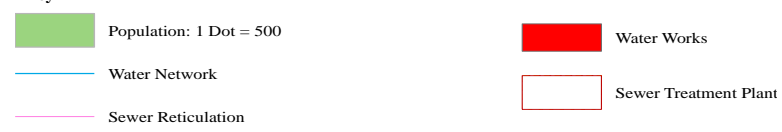

Figure 7. Water supply network and sewerage reticulation for period 1999-2014

The data on total length of water supply network and sewerage reticulation collected for the urban area was compared with the population growth in the period under study. The result showed that the population was high even with decreased growth rate. On the other hand there was a low increase in length of water supply network for the period 1989-1999 but there was a high percentage increase in the period 1999-2014. The implication of these results is that although there was a relatively high percentage increase in the water supply network in the period 1999-2014, the previous periods had recorded very minimal growth that was inadequate in serving the population. The study revealed that the water supply network coverage was approximately $86 \%$ of the total area served by NAWASSCO. The study also showed that the quantity of water that was treated and supplied to the residents was 40,000 
$\left(\mathrm{m}^{3}\right)$ /day. The demand of water for this area was 70,000 $\left(\mathrm{m}^{3}\right) /$ day and the demand-supply gap was $30,000\left(\mathrm{~m}^{3}\right) /$ day.

The percentage increase in sewerage reticulation for the period 1989-1999 was low but there was a relatively high percentage increase in the period 1999-2014. Due to increase in population the company has and is currently replacing the old sewer lines with larger ones to cater for the growing population. Records from the NWASSCO accessed during the study revealed that there was $20 \%$ coverage of the sewerage reticulation that serves the residential areas in some parts of Nakuru municipality but does not extend to the peri-urban areas.

\section{Discussion}

The results indicate that in general the population of Nakuru Municipality has been increasing and Nakuru Municipality was recorded as the fastest growing urban area East and Central Africa (UN-HABITAT \& UNEP, 2010). The finding from the analysis of the satellite images show that the growth of the built-up area has also increased through densification of the urban core and expansion to the peri-urban area and this can be attributed to the increased population of the urban area. Records from KNBS (1994, 2000 and 2010) showed that, the population growth registered an exponential pattern in all parts of the country and this could be the reason for the observed increase in the built-up area. However, the rate of population growth has been declining and stood at 3.05\% in the year 2012 (GoK, 2013). Nevertheless, the population in the study area will remain high due to population growth trajectory (UN, 2017). Mubea \& Menz, (2012) averred that in Nakuru Municipality there was a change from non-urban to urban of $215.2 \%$ in the CBD in the period 1986-2000 and 2000-2010. The expansion seen in the peri-urban area may have been influenced by the ballooning market nodes and development of road network in these areas.

A study carried out by Katyambo \& Ngigi (2017), revealed that urban expansion in the Nairobi Metropolitan area was dominated by extension of developments and sprawl in a radial-axial manner at the Nairobi city periphery onto agricultural land in the rural areas. It also showed that the expansion occurred along transport routes from Nairobi city to other urban centres and from the urban centres to Nairobi city. However the expansion of Nakuru Municipality may not occur in a radial-axial manner because of the restriction due to Lake Nakuru National Park to the south of the town and the Menengai crater to the northern side. Studies carried out in Africa and Asian metropolitan areas including Nairobi revealed that urban growth was dominated by extension and densification and that most of the changes occurred at the outer parts of the metropolitan areas with the possibility of the suburban centres being included into the urban core and form larger urban areas (Murayama et al., 2017).

The low increase in the length of water supply network in 1989-1999 could be attributed to the then on-going reforms in the water sector nationally which delayed implementation of projects geared towards improvement of infrastructure and capacity building in Nakuru town and surrounding peri-urban area. The projects were implemented after enactment of the Water Act 2002 and are evident from the records of 1999-2014 water supply networks. However, it is evident that much of the increase seen in 1999-2014 water supply networks could be due to 
the pipes carrying water from boreholes to feed the water treatment plant (Figure 6).

The completion of the Rift Valley water supply and sanitation project in 2012 that was funded by African Development Bank sought to improve the water supply and sanitation in Nakuru town by increasing water production from less than $30,000 \mathrm{~m}^{3} /$ day to $50,000 \mathrm{~m}^{3} /$ day. This was achieved through development of eight (8) boreholes with $21 \mathrm{~km}$ transmission main at the new well field providing $15,000 \mathrm{~m}^{3} /$ day including rising main pump and control panel. Another achievement was the restoration of existing groundwater sources, water supply and bulk transfer systems from surface water that provided a total of $26,700 \mathrm{~m}^{3}$ as per their design capacities through drilling three (3) new boreholes and rehabilitation of the existing ones (RVWSB, 2012). However the current water distribution system is inadequate to the extent that it may not cope with increasing demand. Inadequate supply of water could adversely affect the attainment of SDGs, Kenya Vision 2030 and the Big Four Agenda as set by the government. It has been argued that water is core to sustainable development and it is critical for health ecosystems and human survival (WWAP, 2015). Water is necessary for reducing global burden of diseases and improving the health, welfare and productivity of the population. Water is needed in agricultural, industrial and environmental sectors. Insufficient water supply has implications on food security, employment and in general poverty reduction strategies. Hence it is important to ensure that citizens are supplied with this basic commodity for human development.

This finding is in agreement with a study which showed that urban population growth out paces expansion of improved water supply sources (UNDP, 2006). Increase in the water supply infrastructure does not also necessarily translate to increased water supply to households as evidenced in the survey where some peri-urban areas have the infrastructure but no water is supplied to them. UNDP (2006) noted that the shortage in supply of water is rarely the underlying problem, but the uneven distribution. Castro (2007) concluded that water deficiency is a crisis of governance more than unequal physical distribution and proposes social participation as fundamental to control conflicts, risks and uncertainties in water supply.

Extension of sewer lines in urban area by $18 \mathrm{~km}$ including rehabilitation of existing sewer disposal system was completed in 2012 and this is what contributed to the observed increase albeit small in the length of sewerage reticulation in the period 2009-2014 (RVWSB, 2012).WASREB (2018) records an average of $16 \%$ sewerage reticulation nationally which is far below the policy goal under Vision 2030 to increase sanitation coverage in urban areas to $100 \%$ by increasing coverage of sewerage system to $80 \%$ and installing improved on-site treatment facilities for populations not covered by sewerage systems.

Mapping of the trends of extent of urban growth, water supply and sewage reticulation with population increase show there is increase in built-up area and the supply of water and sewerage reticulation has also increased slightly as the population of the area increased. The population growth increase implies that there was need for various urban services including housing, commercial and business centres hence the increase in the built-up area. The larger town's population is concentrated within the existing municipal boundary that have 
well-established, serviced and accessible housing estates in Central Business District and south of the Central Business District, and the main industrial area. Another area with high population concentration is located directly north and south of the eastern industrial area on either side of Nakuru-Nairobi highway due to the availability of cheap land for housing development by private initiatives. However these areas are not well serviced and lack basic support and essential community facilities such as water supply system and sewerage reticulation. The densification of the built-up area impacts the supply of water and sewerage system services. The implication of this finding is that the original water supply and reticulation system was designed for a small population of residents in the area who were adequately served but with densification in the area, the demand for these services has increased tremendously thus straining the existing system. However densification of the urban area could be advantageous in terms of improving the water supply and sewerage reticulation because where these systems already exist, what is needed is extension to the areas not served. Expansion that may be a characteristic of urban sprawl means that there is need for development of water supply and sewerage reticulation which is a costly venture that needs proper planning and budgetary allocation. Low cost option for waste water management such as on-site waste water treatment can come a long way in solving the problem of inadequate sewer system in both the urban and peri-urban areas. They also offer the benefit of harnessing resources such as water, compost, fertilizers, soil conditioners, biofuel and biogas.

The rate of increase in water supply to the residential area was higher than that of the sewerage reticulation. This shows that there is less attention given to waste water disposal. This poses a challenge in grey water management since the supply of water far exceeds sewage reticulation. This grey water finally flows into nearby river and ultimately into Lake Nakuru. Waste water contains about $99 \%$ of water and only $1 \%$ waste matter. This shows that there is a high potential of harnessing a substantial amount of water from waste water. Waste water recycling is not a new phenomenon. Several cities globally are recycling waste water and using it for cleaning purpose and even for drinking. According to Daniels (2008), the new mantra for water use is reduce, reuse and recycle. Recycling waste water has also the benefit of extracting energy from the sludge which creates new opportunities for income generation and enlarges the resource base available to poor households especially in developing countries. Briquettes made from sewer sludge have energy content that are comparable to those of commercial charcoal briquettes making them a potential substitute that also contributes to the preservation of the environment (Ward et al., 2014).

\section{Conclusion and Recommendation}

The study has shown that there was growth of the urban area mostly densification of the urban core but there was also expansion into the peri-urban areas. There was also a rapid increase in built-up area in tandem with population increase over the years under study. The rate of increase in urban extent far outweighs the increase in the growth of the water supply network and sewerage reticulation in Nakuru municipality and surrounding peri-urban area and hence it is insufficient to meet the daily needs of the residents. This deficiency can be addressed through collaboration of all stakeholders in urban planning and in the water sector. 
Waste water recycling can be an alternate way of reducing the deficiency. However, there is need to create public awareness on the use of treated waste water as this may not be culturally acceptable.

\section{Acknowledgement}

The research was funded by the Association of Africa Universities (AAU) and Egerton University.

\section{References}

Daniels, T. (2008). Taking the initiative: why cities are greening now. In E. L. Birch \& S.M. Wachter, (Eds.), Growing greener cities- urban sustainability in the twenty-first century. (pp. 11-27). Philadelphia: University of Pennsylvania Press

Castro, J. E. (2007). Poverty and citizenship: Sociological perspectives on water services and public-private participation. Geoforum, 38, 756-771.

https://doi.org/10.1016/j.geoforum.2005.12.006

Freudenberg, N., Galea, S., \& Vlahov, D. (2005). Beyond urban penalty and urban sprawl: back to living conditions as the focus of urban health. Journal of Community Health, 30(1), 1-11. https://doi.org/10.1007/s10900-004-6091-4

Garza, G. (2004). The transformation of the urban system in Mexico. In T. Champion \& G. Hugo (Eds.), New forms of urbanization: beyond the urban-rural dichotomy. Aldershot: Ashgate Press Government of Kenya (GOK) (2008). Medium term plan (2008-2012). Nairobi, Government Printer.

Government of Kenya (2013). Nakuru county First County integrated development plan (2013-2017). Nairobi, Government Printers.

Katyambo, M. M., \& Ngigi, M. M. (2017). Monitoring of urban growth using GIS and remote sensing: A case study of Nairobi metropolitan area, Kenya. American Journal of Geographic Information System, 6(2), 64-82. http://doi.org/10.5923/j.ajgis.2017.0602.03

Mubea, K. W., \& Menz, G. (2012). Monitoring land-use change in Nakuru (Kenya) using multi-sensor satellite data. Advances in Remote Sensing, 1(3), 74-84.

https://doi.org/10.4236/ars.2012.13008

Murayama, Y., Kamusoko, C., Yamashita, A., \& Estoque, R. C. (Eds.) (2017). Urban development in Asia and Africa geospatial analysis of metropolises. The urban book series. https://doi.org/10.1007/978-981-10-3241-7

Mwangi, I. K., Maleche, Z., Mochache, J., Mairura, O. E., \& Obiero, S. (2010). Nakuru strategic structure plan phase 2: sectoral studies report- summary report, Volume 1; Nairobi, DURP.

Kenya National Research Council (NRC-USA) (2003). Cities transformed: demographic change and its implications ii the developing world. Washington, DC: National Academies Press. 
RVWSB (2012). Project completion report. OWAS Department; African Development Bank [Online] Available:

https://www.afdb.org/.../Project.../Kenya\%20-\%20Rift\%20Valley\%20Water\%20Supply

UN (2010). World urbanization prospects: The 2009 revision. Department of economic and social affairs, population division. New York, NY: United Nations. [Online] Available: http://www.un.org>population

UN (2015). World urbanization prospects: The 2016 revision. Department of economic and social affairs, population division. New York, NY: United Nations. [Online] Available: http://www.un.org>population

UN (2017). World urbanization prospects: The 2017 revision. Department of economic and social affairs, population division. New York, NY; United Nations. [Online] Available: http://www.un.org>population

UNDP (2006). Human development report. beyond scarcity: Power, poverty and the global water crisis. New York, NY: UNDP. [Online] Available: http://hdr.undp.org/hdr2006/

UN-HABITAT (2008). Harmonious urbanization: The challenge of balanced territorial development. The fourth world urban forum 2008. Nairobi, UN HABITAT. [Online] Available: http://mirror.unhabitat.org/pmss/getElectronicVersion.aspx?nr=2446\&alt=1

UN-HABITAT \& UNEP (2010). The state of African Cities 2010: Governance, inequality and urban land markets. Nairobi, UN- HABITAT. [Online] Available:

https://unhabitat.org/.../state-of-african-cities-2010-governance-inequalities-and-urban

UN-HABITAT (2014). State of African cities 2014: Re-imagining sustainable urban transitions. Nairobi, UN HABITAT. [Online] Available:

https://unhabitat.org/.../state-of-african-cities-2014-re-imagining-sustainable-urban-transition

Ward, B. J., Yacob, T. W., \& Montoya, 1. 2014). Evaluation of solid fuel char briquettes from human waste. Environmental Science and Technology, 48(16), 9852-9858.

https://doi.org/10.1021/es500197h

Water Services Regulatory Board (2016). Impact: A Performance report of Kenya's water services sub-sector. Issue No. 9. Nairobi, WASREB. [Online] Available:

https://wasreb.go.ke/downloads/WASREB_IMPACT_Issue9_FINAL.pdf

Kenya Water Services Regulatory Board (2018). Impact: A Performance Report of Kenya's Water Services Sub-sector. Issue No. 10. Nairobi, WASREB. [Online] Available:

https://wasreb.go.ke/downloads/WASREB_IMPACT_Issue10_FINAL.pdf

WWAP (United Nations World Water Assessment Programme) (2015). The United Nations world water development report 2015: Water for a sustainable world. Paris, UNESCO. [Online] Available:

http://www.unesco.org/new/en/natural-sciences/environment/water/wwap/wwdr/2015-water-f or-a-sustainable-world/ 


\section{Macrothink \\ Environmental Management and Sustainable Development \\ ISSN 2164-7682}

\section{Copyright Disclaimer}

Copyright for this article is retained by the author(s), with first publication rights granted to the journal.

This is an open-access article distributed under the terms and conditions of the Creative Commons Attribution license (http://creativecommons.org/licenses/by/3.0/). 